\title{
László Muraközy
}

\section{Freedom of the Markets versus Good Governance Experiences in Central Europe}

\begin{abstract}
The market and the state, operation and characteristics of two institutions of key importance in the modern mixed economies, are investigated for the former socialist countries in this study. After two decades it can be seen more clearly what system has been established in the region, how it operates, and what its characteristics are. In the first part of the with the help of international comparisons we examine how free the market is, how good the rules are, and how much they help, or hinder, the fulfilment of its function. From an other aspect we compare the scope of the good governance and the size, the freedom and efficiency of the state. According to the evidence of the international studies examined, the former socialist countries established the forms of the market institutional system relatively quickly, but the operation and quality of these lagged significantly behind those of the developed countries. Also important conclusion of the study is that by the first decade of the millennium the characteristics of the former socialist countries are increasingly diverging from one another. Both the characteristics of the earlier socialism, and the more distant historical past which can be caught in the act within it, had and have an effect on the economic and social systems now established in Eastern and Central Europe.
\end{abstract}

Journal of Economic Literature (JEL) codes: H1, P17, P27, P35

Keywords: Performance of Government, public economics, international comparison

Two decades have passed since 1990 when in Central Europe and further to the east the socialist systems collapsed and a historical transformation began: the adoption, introduction and domestication of the pattern of mixed economy established in the developed countries. Through a series of great hopes, endeavours and mistakes, the foundations of the new economy were laid in most countries during the first decade, a majority of private ownership was established, the institutions of market economy were organised and in the fortunate countries all this was accompanied by the introduction of democracy. Institution building, partially at the suggestion of international institutions and consultants and partially in a spontaneous way, was based far more on the adoption of forms already established in the developed countries, rather than on their own, scarcely existent traditions, or on internal evolutionary forms. "Time's Arrow" (Hayek 1989:151) played a significant role here; Hayek thus referred to the adoption of institutions formed in an evolutionary way elsewhere. This can be "time's arrow" as it accelerates development, but at the same time the dangers of "organ transplant" can arise, in which the foreign environment may reject the institution obtained from elsewhere, or at least, it may result in dysfunctional operation. The opinion expressed 
by North and his co-authors in their book (North-Wallis-Weingast 2008) essentially implies that it is impossible to copy the successful institutional system of the western way.

The operation and characteristics of two institutions of key importance in the modern mixed economies, the market and the state, are investigated for the former socialist countries in this study.. After two decades it can be seen more clearly what system has been established in the region, how it operates, and what its characteristics are. In the first part of the study an attempt is made to take stock of the "facts", then in the second, to analyse the operation of the institutions in our region based on the facts and theoretical considerations.

\section{Facts and tendencies}

Freedom of the markets

The market is one of the most complex institutions, and whilst it is of informal character in many of its manifestations, formal rules and institutions are indispensable for its satisfactory operation in the modern form. In today's mixed economies, the adequacy and quality of state, legal regulation are of key importance for operation of the markets. Precisely for this reason, evaluation of market operation may and must be approached from several angles. We must examine how free the market is, how good the rules are, and how much they help, or hinder, the fulfilment of its function. In order to analyse these areas, which are difficult to measure, I have applied the Economic Freedom of the World index (Gwartney-Lawson 2009), long used and perfected by the Fraser Institute, which spans several decades between 1970 and 2007, and which expanded its investigation from the beginning of the nineties to include the socialist countries ${ }^{1}$.

The Economic Freedom of the World also examines several important subterritories, or produces a complex index as a derivation of these. The main territories:

- size of government, (expenditures, taxes, enterprises)

- legal structure and security of property rights (Rule of Law)

- access to sound money

- freedom to trade internationally

- credit market regulation

- labour market regulation

- business regulation

The investigation is focused on the extent to which indispensable regulation guarantees market freedom, overall or in the most important territories. How much does it restrict or promote this freedom?

\footnotetext{
1 The index displays the values on a scale of 0 to 10. 10 signifies total freedom. Here in the study the indices have been transformed into values between 0 and 100, (multiplying the original value by ten), for the sake of easier comparison with the rest of the data under investigation.
} 


\section{Average values of the Indexes of the Economic Freedom between 1970 and 2007 (53 countries)}

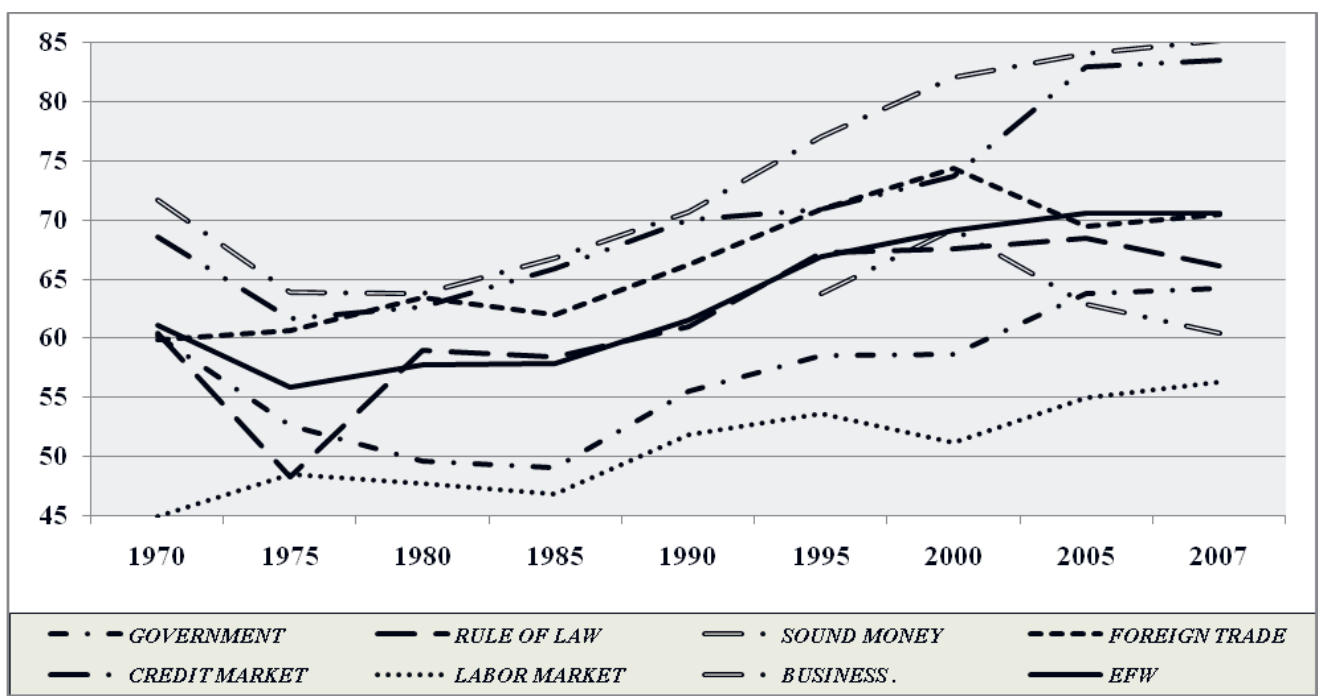

Source: Gwartney-Lawson 2009

Figure 1 presents the average trends in the main indices in the period between 1970 and 2007, taking into account data from 53 countries. Figure 2 shows the same averages for 121 countries for a more restricted period, between 1995 and 2007. Figure 1 shows changes in the main indices over close to four decades, with respect to more than fifty countries. The first thing worthy of attention is that the period of crisis during the seventies checked the growth of economic freedom. The reduction occurred both on the credit and money markets, with a relatively high degree of freedom, and for the indices characteristic of the governmental and legal environment. Trends in the money and credit market are typical of a boom to a significant extent, whereas the other two areas indicate that more powerful state intervention than formerly has occurred in the crisis. The fallback and stagnation of economic freedom lasted right up till the second half of the eighties, and in the nineties it once again attained the level of two decades before. The turnaround occurred first of all in the credit and money markets. The upward trend begins here in the eighties, but here too, it is only in the nineties that the level of the early seventies is attained. 


\section{Average values of the Indexes of the Economic Freedom between 1995 and 2007 (121 countries)}

Figure 2.

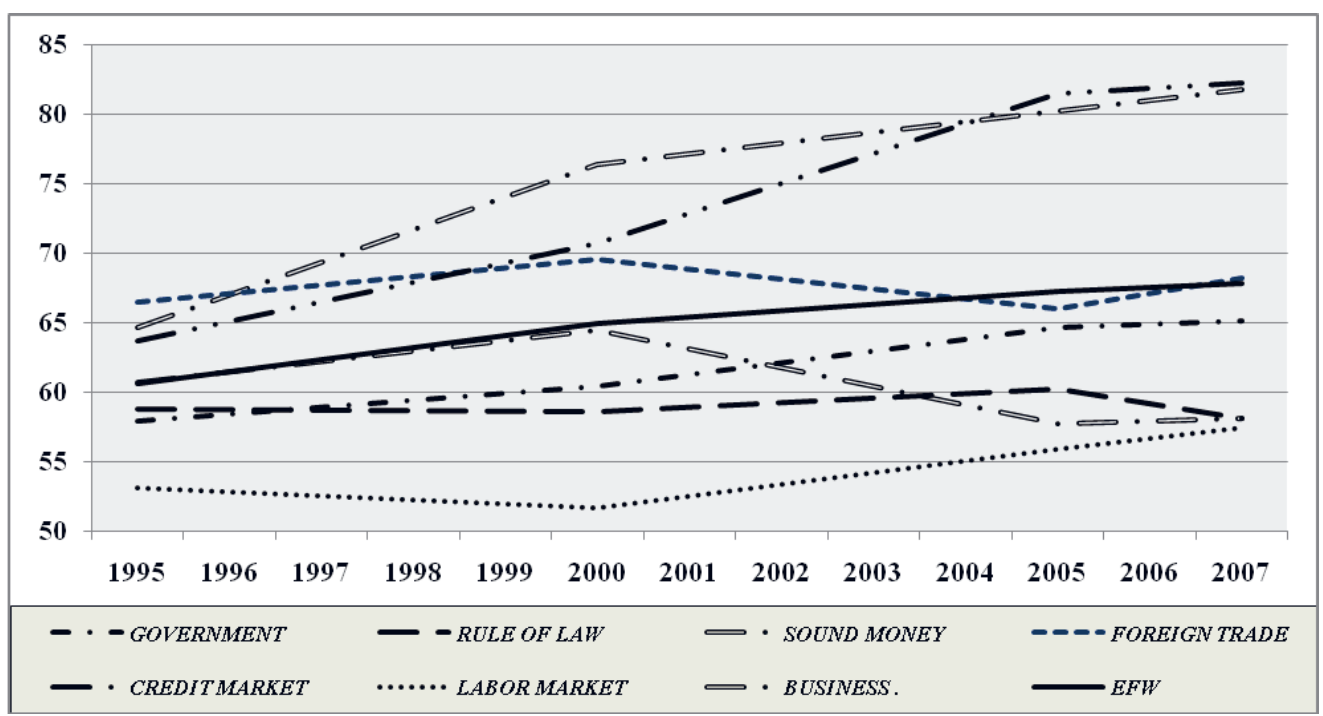

Source: Gwartney-Lawson 2009

The nineties arrive with a decade of raised hopes, quiet growth and expanding globalisation. Freedom of the markets is growing, besides the money markets and foreign trade the bonds of the labour market have also been loosed, but restraints on the government and the legal system have also eased. It is further observable, however, that economic freedom is relatively greater in the money and credit markets, and in the area of foreign trade, and this is served less by the role of the government, and the labour market is traditionally stiff and inflexible. These deviations appear particularly strikingly in the developed countries of Europe. This ranking according to order of magnitude is also similar in the leading overseas economies, but there, a greater economic freedom may be observed overall, and particularly in the areas of government and the labour market.

The final years of the nineties and the turn of the millennium mark another turnaround. Growth of economic freedom slows down, particularly in the areas of the labour market and the government. Freedom in foreign trade is restricted in the decelerating world economy after 2000, and business opportunities worsen. Interestingly, and even then as a warning sign, the greatest growth in freedom occurs in the credit markets after a more moderate rise in the nineties, and together with this, freedom of the money markets is also very high. A kind of global "runaway" in the money and credit sphere was perceptible even before the crisis of $2007 / 2008$.

The changes occurring from the mid-nineties can be examined on a broader national pattern, as data from more countries are available from that time. In Figure 2, trends in the indices can be seen with respect to various areas of economic freedom, now extending to 121 countries. This considerably larger sample draws a broader sphere of less-developed countries into range. The main tendencies show a similar pattern to the previous sample. 
A striking change can be observed after the turn of the millennium: alongside the rising freedom of the money and credit markets, the freedom in foreign trade is reduced and the business freedom index worsens. A small scale improvement is perhaps perceived after 2005, but as we know, this period was the calm before the storm, as the storm of the financial and economic crisis has by now thoroughly rearranged the picture. After the turn of the millennium, therefore, the economic standstill can be felt in the real economy, but not at all in the area of the financial and credit sphere, indeed, the opposite tendency is more perceptible there.

We naturally have no data with regard to next year, but based on long term experience, tendencies observable in the seventies and eighties, and the development of economic policy in recent years, a reduction in economic freedom is to be expected, with increasing interference and regulation by the government. And the recession could injure foreign trade, the business environment and the condition of the labour market. Based on present developments, this could be an effect perceptible even over longer periods, which could make emergence of the awaited upswing more difficult. A vicious circle could be established, restriction of the markets and a broadening intervention, in spite of good intentions, could make growth more difficult, which may possibly stimulate the regulators and governmental players to renewed activity.

In terms of our subject it is particularly important to see how the various elements of market freedom developed in the former socialist countries during the period of transformation and institution building, which occurred incredibly rapidly from a historical perspective. Figure 3 shows the trends in the economic freedom indices in the period between 1995 and 2007 for 15 widely differing former socialist countries ${ }^{2}$. These countries, with very different historical, developmental and cultural features, were facing similar challenges during this period, to build the market and establish the basic institutions of a mixed economy.

2 The Visegrad Group, with Slovenia also listed here, the Baltic States, in the southern group Croatia, Romania, Bulgaria, Albania and two CIS countries, Russia and Ukraine, as well as China. 


\section{Average values of the Indexes of the Economic Freedom between 1995 and 2007 ( 15 former socialist countries)}

Figure 3.

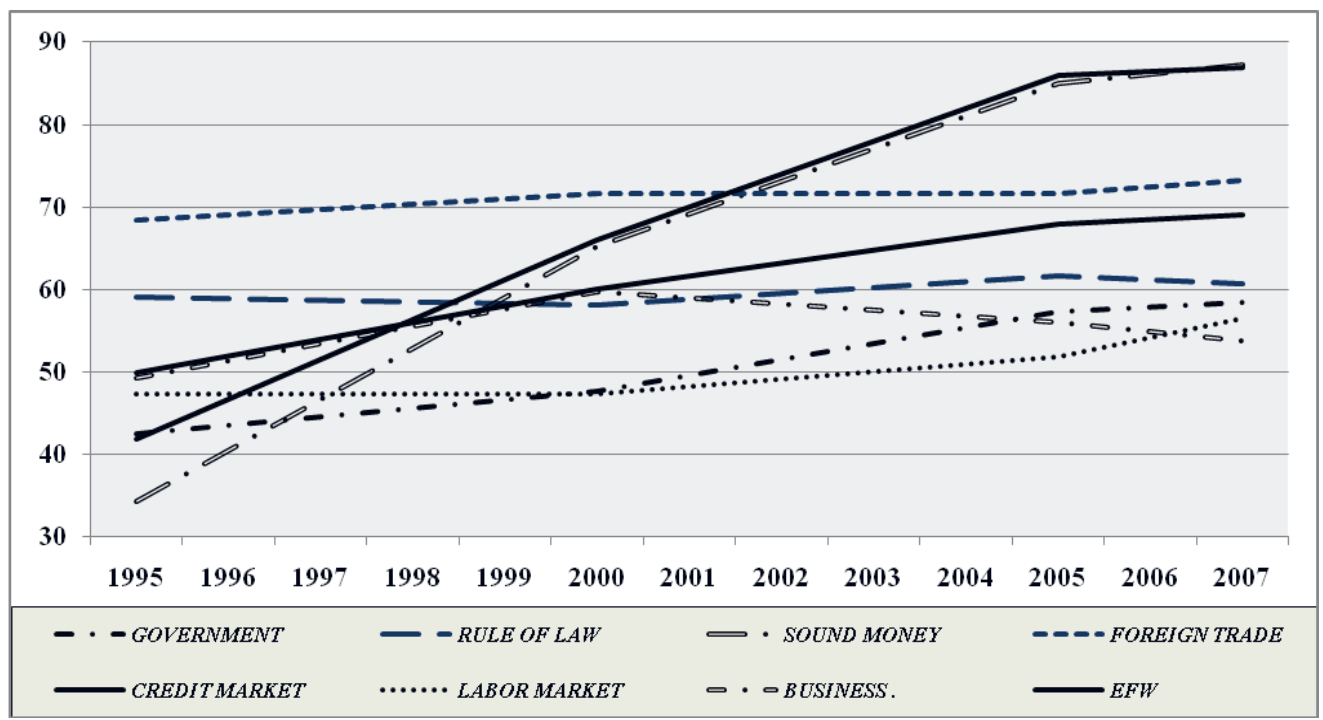

Source: Gwartney-Lawson 2009

The most dynamic, even tempestuous changes for the economies under transformation are shown by the freedom index of the money and credit market. From a 30-40 percent value, in a decade they attained values close to 90 percent of that of the developed European economies, in fact, the Baltic States even exceeded this. Foreign trade and the legal system remain largely on the same level in this period, the freedom of the labour market and the government index climb slowly. Business freedom rises until the turn of the millennium and afterwards slowly decreases, similarly to the developed countries. The aggregate freedom index does in fact rise, but a deciding factor in this is a jump in the increase in freedom of the credit and money market. In truth the change between 1995 and 2007 is surprisingly small, if the credit and money market indices are disregarded. Of the individual groups of economies in transformation, the economic freedom index is largest for the Baltic States, almost identical to that of the developed European countries. The state is also the freest here, distancing itself perhaps excessively from economic issues, though the price for this was paid in the crisis. (Csaba 2009) The Visegrad Group comes next, in this study including Slovenia, which is similar in many ways. The southern states come next, with China and Russia at the end. It can be stated, therefore, that the most developed groups of the former socialist countries, the Baltic States and the Visegrad Group, in respect of the economic freedom index had largely fallen into line with the developed European economies by the middle of the first decade of the third millennium. The development of Hungary also fits in with this trend, as can be sensed from Figure 4 . 
Figure 4.

\section{Indexes of the Economic Freedom in Hungary between 1990 and 2007}

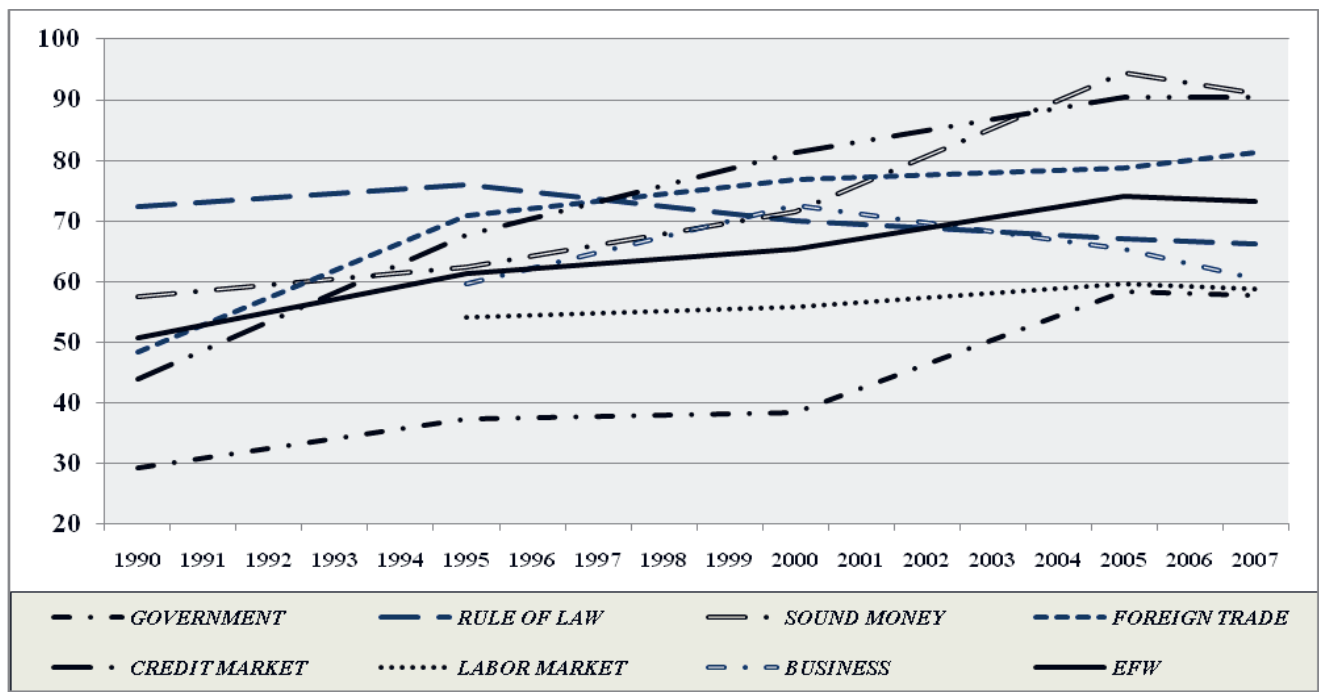

Source: Gwartney-Lawson 2009

The average index of economic freedom rose continuously in Hungary between 1990 and 2007, but here too the money market and the credit market is the decisive driving force, in particular between 1990 and 1995, as well as between 2000 and 2005. It appears peculiar, however, that the freedom index for the legal requirements system has been falling since 1995. Remission of the business freedom index after 2000, on the other hand, follows international tendencies. The government index is very low in the nineties, though this improved somewhat in the decade from 2000. 2005 shows a break in the case of Hungary, growth of almost all the indices came to a halt.

The forms of the market institutions, with emphasis on the word forms, were more or less established in the Visegrad and Baltic States, according to the evidence of the economic freedom indices. According to experience, however, these did not operate anywhere near as well as in the developed countries. It is worth taking a good look at the quality of operation, in order to obtain a more subtle picture of the transformation process.

\section{Good governance}

The international study examining the expansion of economic freedom as analysed in the previous section primarily compares the formation and developmental state of the institutional frameworks. More information on the nature and quality of their operation can be obtained from the World Bank Worldwide Governance Indicators (WGI) project, which has already extended its survey to 212 countries (Kaufmann-Kraay-Mastruzzi 2009). Those who produced the material have summarised their approach as follows: "We define governance broadly as the traditions and institutions by which authority in a country is exercised. This includes the process by which governments are selected, monitored and 
replaced; the capacity of the government to effectively formulate and implement sound policies; and the respect of citizens and the state for the institutions that govern economic and social interactions among them." (Kaufmann-Kraay-Mastruzzi 2009:5)

The six dimensions of governance that they measure corresponding to their definition are:

- Voice and Accountability

- Political Stability and Absence of Violence

- Government Effectiveness

- Regulatory Quality

- Rule of Law

- Control of Corruption

As can be seen, the study attempts to grasp the correct operation of the institutions in these six dimensions ${ }^{3}$. Data from this study with respect to 2007 are presented in Figure 5 for a number of country groups and for Hungary. It can be clearly perceived from Figure 5 that compared with the developed European market economies, even the most developed countries in transition are lagging behind to a much more significant extent than in the case of the economic freedom indices examined above. The Visegrad and the Baltic States are on a closely similar level, but a much larger divergence is seen for the rest of the former socialist countries. This indicates that though the institutional forms may be similar in many ways to those in the model countries, the efficiency and quality of their operation lag significantly behind.

Indexes of the World Governance Indicators -2007

Figure 5.

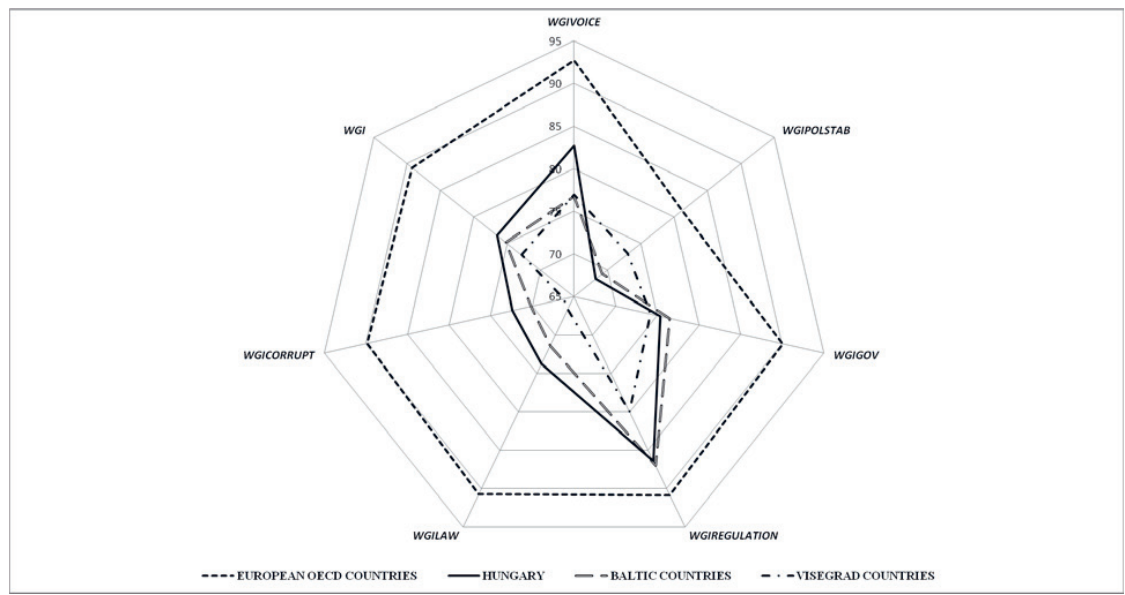

Source: Kaufmann-Kraay-Mastruzzi 2009

\footnotetext{
${ }^{3}$ A methodological description of the World Governance Indicators may be found in: Kaufmann - Kraay - Mastruzzi, 2009. In the individual areas, the indices show the ranking of the individual countries by percentage. In contrast to the Economic Freedom of the World test, experts of the World Bank do not use a single, totalised WGI index, aggregated from the six indices, taking into account the differences between the areas, which are clearly very diverse in character. In this study I regard the average of the 6 aggregated indices as the WGI index, but I also place more emphasis on the individual territories.
} 
The WGI indices for one country from each of the groups of former socialist states mentioned above are shown in Figure 6. Of these, Hungary and Estonia lie closest to the developed European countries, Russia and Albania the furthest away, and Romania occupies an intermediate position. In general, the divergence is smaller in the indices for regulation and democratic forms, and is the largest in the area of corruption and the rule of law.

\section{Indexes of the World Governance Indicators in some former socialist countries -2007}

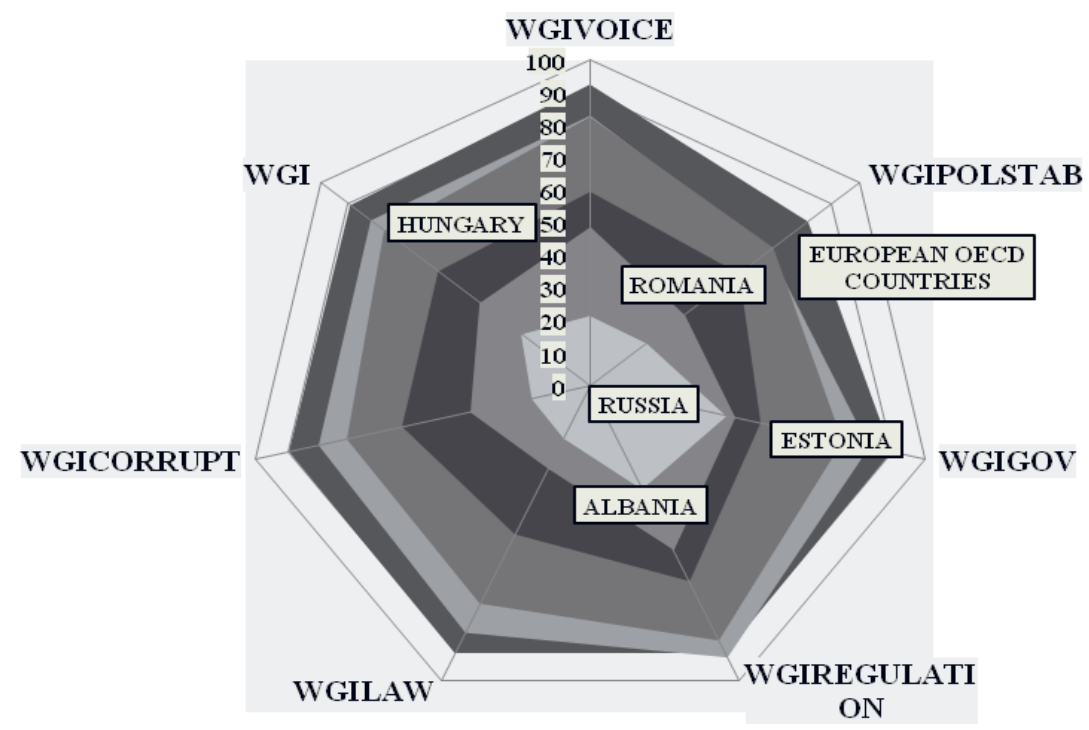

Source: Kaufmann-Kraay-Mastruzzi 2009

The values of the Economic Freedom of the World index with respect to 2007 are shown in Figure 7 for these same countries. A comparison of the two figures speaks for itself. In contrast to the WGI indices, the EFW indices of the countries under investigation are much closer to one another, and it is not at all certain that the economic freedom measured here is greater in a more developed country. The government, for instance, is the freest in Albania, the labour market in Romania, the business sphere and credit market in Estonia, though in fact everything is very free everywhere, just like the money market. In the developed Western European countries, on the other hand, the rule of law is higher than in the former socialist states featured here.

It can be experienced from a comparison of the two extended international studies, and by taking broader contexts into account, that the international expansion of institutional forms may be rapid, but at the same time this does not mean that after their adoption and domestication they will work in a similar way to where they have been present for a long time. Good institutional operation depends on a huge number of factors, and in the developed countries many decades were needed for their evolution and for concerted 
operation. The WGI indices have only been available for just over a decade, but during this period the values in the developed countries have shown great stability, the ranking, index and positions of the individual countries with respect to one another have not changed much. This also indicates that the nature and quality of operation of the institutions is a result of complex factors and to a large extent is based on historic, traditional considerations, which themselves are slow to change. In the decade in question, the political stability index worsened in general in the developed countries, whilst that of regulation improved in most cases; the rest, on the other hand, display a large degree of stability.

\section{Indexes of the Economic Freedom in some former socialist countries -2007}

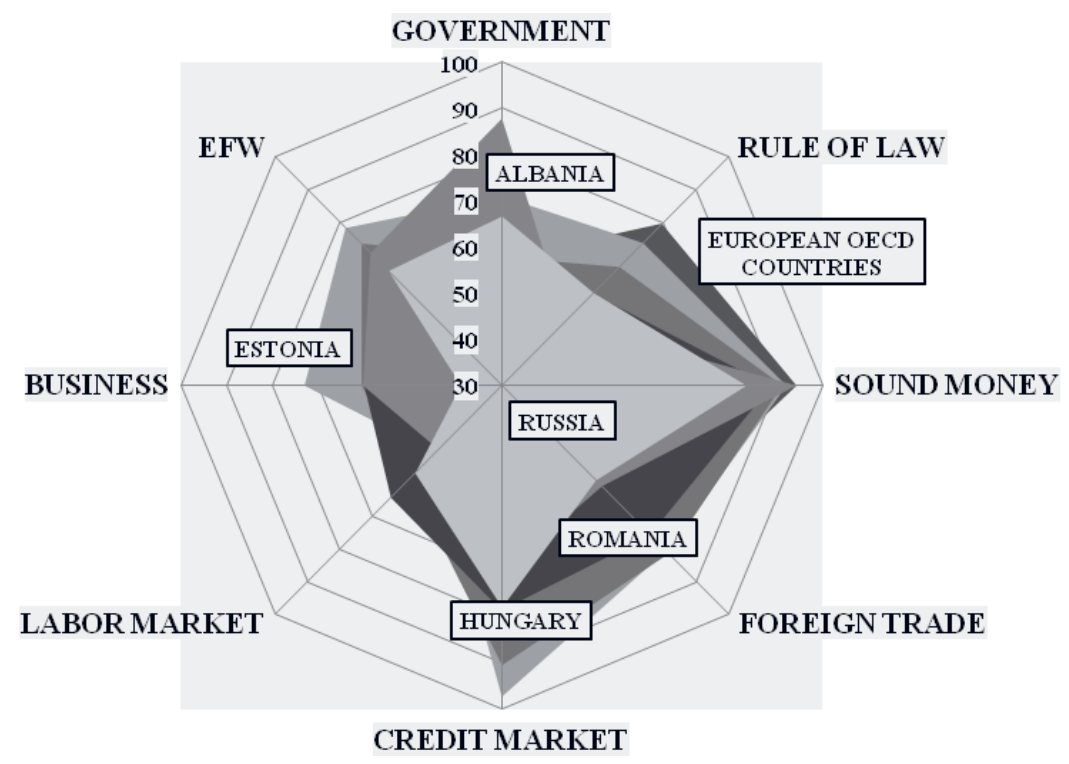

Source: Gwartney-Lawson 2009

Differing levels of quality are also found between the developed European countries with regard to operation of the institutions, as modelled by Figure 8 . The highest level is observed in the Scandinavian countries, the lowest in the states of Southern Europe. The other European countries are positioned between these two extreme cases. In spite of the fact that Hungary occupies a relatively good position among the former socialist countries in terms of the WGI survey, it does lag behind the values of the Southern European countries, apart from the case of the regulation index. The shortfall is the greatest with regard to corruption and the rule of law, in comparison with all three groups of European countries. The institutes of political democracy and market regulation, as also seen on Figure 5, are the two "strongest" territories both in Hungary and in the rest of the former socialist countries. 


\section{Indexes of the World Governance Indicators in Europe and in Hungary - 2007}

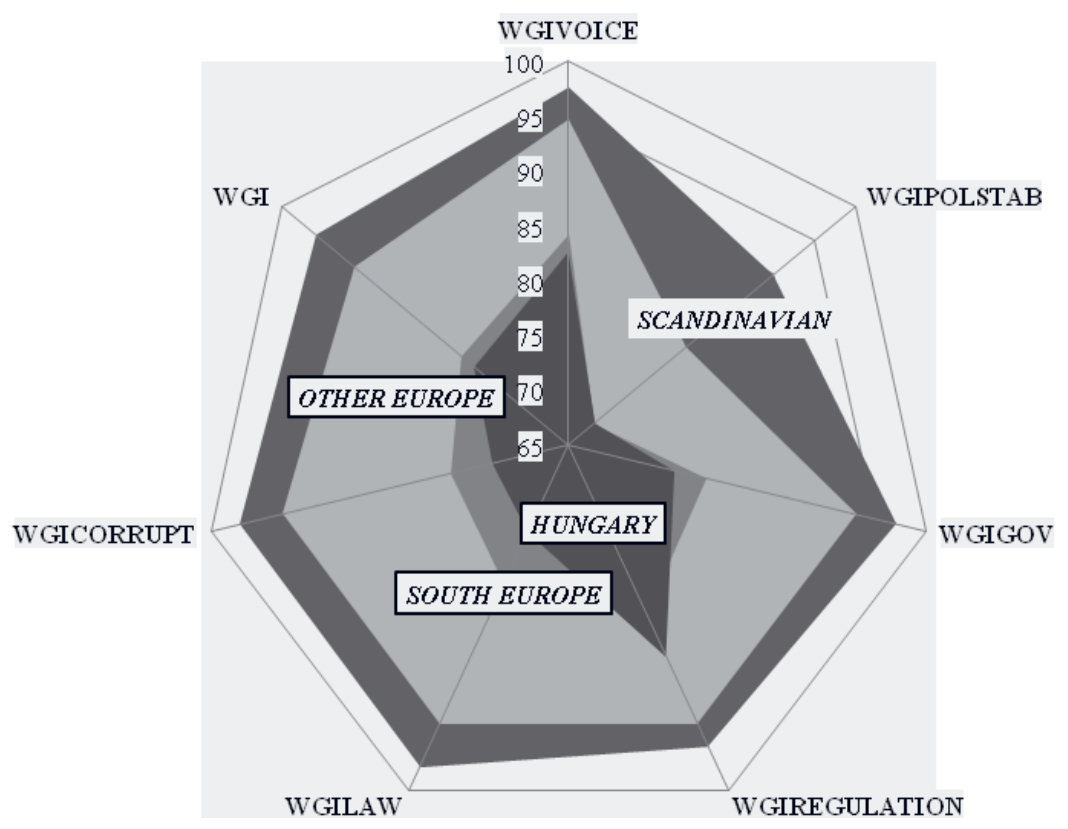

Source: Kaufmann-Kraay-Mastruzzi 2009

According to the evidence of the two international studies examined, the former socialist countries established the forms of the market institutional system relatively quickly, but the operation and quality of these lagged significantly behind those of the developed countries. The formation of this latter, though, is a very slow and complex process, and no abrupt change could or did occur in this from the mid nineties. In the following, besides the market, the development of the role and operation of the other important institution, the state, is investigated separately. This is particularly important in the case of the former socialist countries, as here a centralised planned economy, a society dominated by the state, was replaced by the idea and practice of the dominant mixed economy. The main player in this transformation process in Central and Eastern Europe was, paradoxically, the totalitarian state which was to be deconstructed and transformed.

\section{The size, freedom and efficiency of the state}

The importance of the state may most frequently be estimated by its magnitude, by its size compared with the GDP. This is a very important index or characteristic, even if it clearly provides a quantitative and not qualitative approach to an estimation of the state. International comparisons here are of course made more difficult, in that we cannot speak of unified tendencies or unequivocal trends even in countries of the developed world; very different countries and types are encountered in this area too. 
This is clearly perceived in Figure 9 and Figure 10 too, where based on data from Government Finance Statistics, the magnitude of national expenditure in comparison with the GDP can be seen for 2005, for countries listed in increasing order according to GDP per capita. The highest value is observed for the developed states of Europe, for the leading overseas economies it is lower than this. At the higher developmental level the governmental importance is generally greater, but the scatter is very large at every level. Of the former socialist countries the value for Hungary is very high, and this is followed by Slovenia.

An important question is, how do the governments of various sizes and the national expenditures relate to development of the economic freedom indices examined earlier, and also with the index estimating the quality of "good governance"? In Figure 11, the index with respect to the government is highlighted and presented from among all the EFW and the WGI indices, and compared with the magnitude of government expenditures. These indices are presented with the countries arranged as a function of their state of development. It can be seen that a greater governmental importance generally reduces the measure of economic freedom, but, and this is a very important lesson, the quality of government does not depend on its size, but much more on the developmental state of the country's economy and institutions.

For the order according to developmental state in Figure 11, there is a close correlation between the WGI index related to government and the developmental state. More detailed analyses also show that the quality of governmental activity in closely related to the level of economic development. The varying extent of the role played by the state could also involve similar effects. It is clearly perceived how many different things are meant and how many diverse concepts are covered by the frequently mentioned expressions "major" state or "strong" state

Figure 9.

General government expenditures in 45 countries in the \% of GDP - 2005

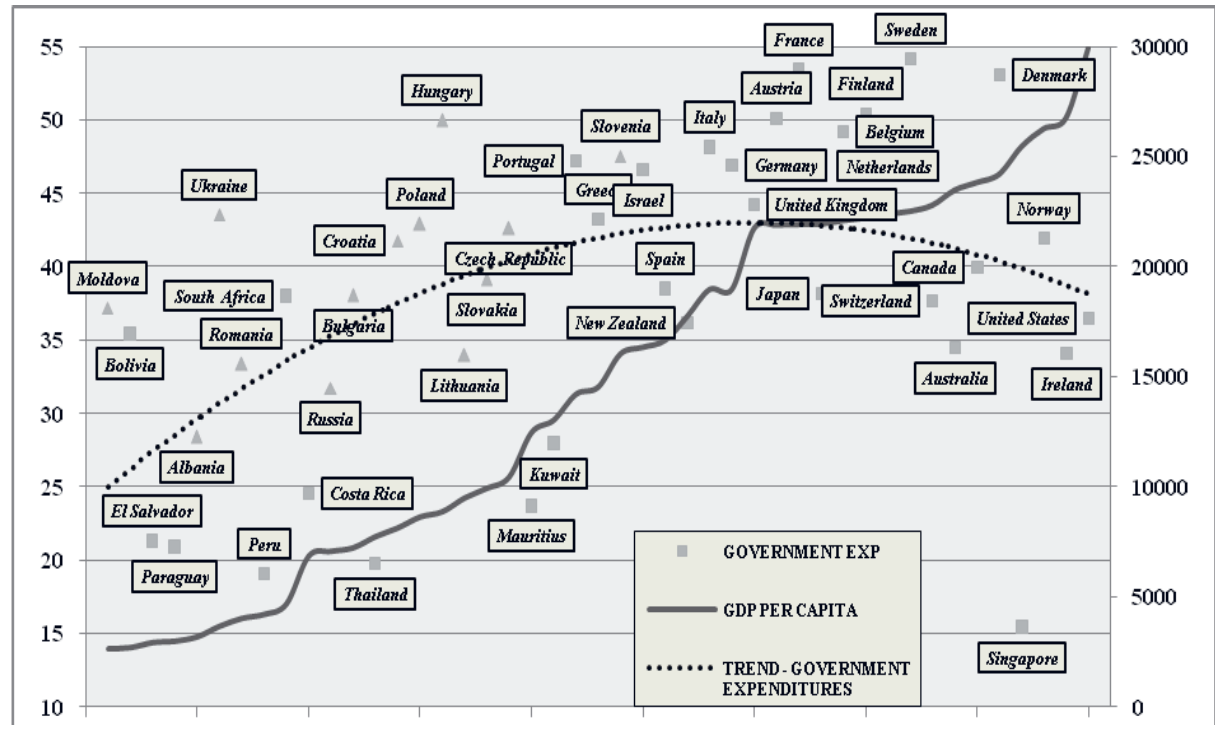

Source: GFS 2007, Maddison 2003, IFS 2008 
Figure 10.

General government expenditures in 26 OECD countries in the \% of GDP - 2007

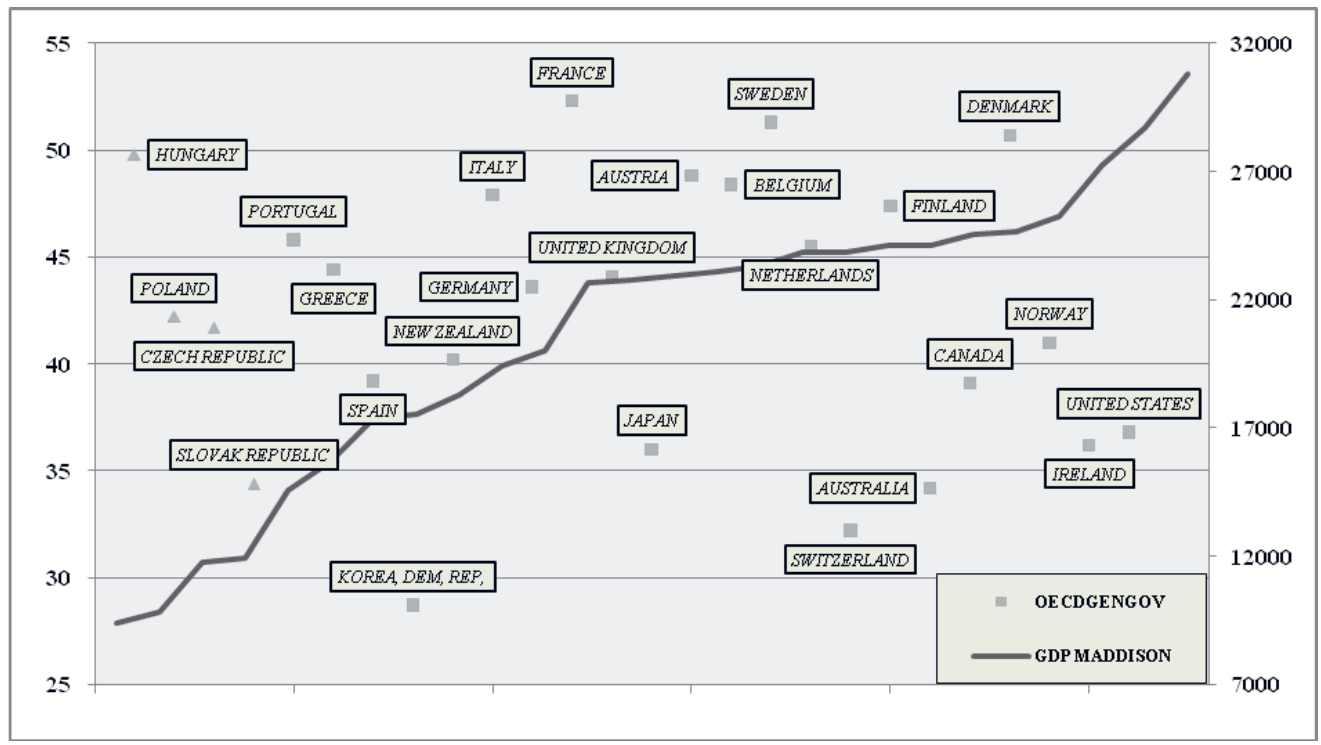

Source: OECD 2009: 295, Maddison 2003, IFS 2008

Figure 11.

General government expenditures and WGI Government indexes - 2005 (45 countries)

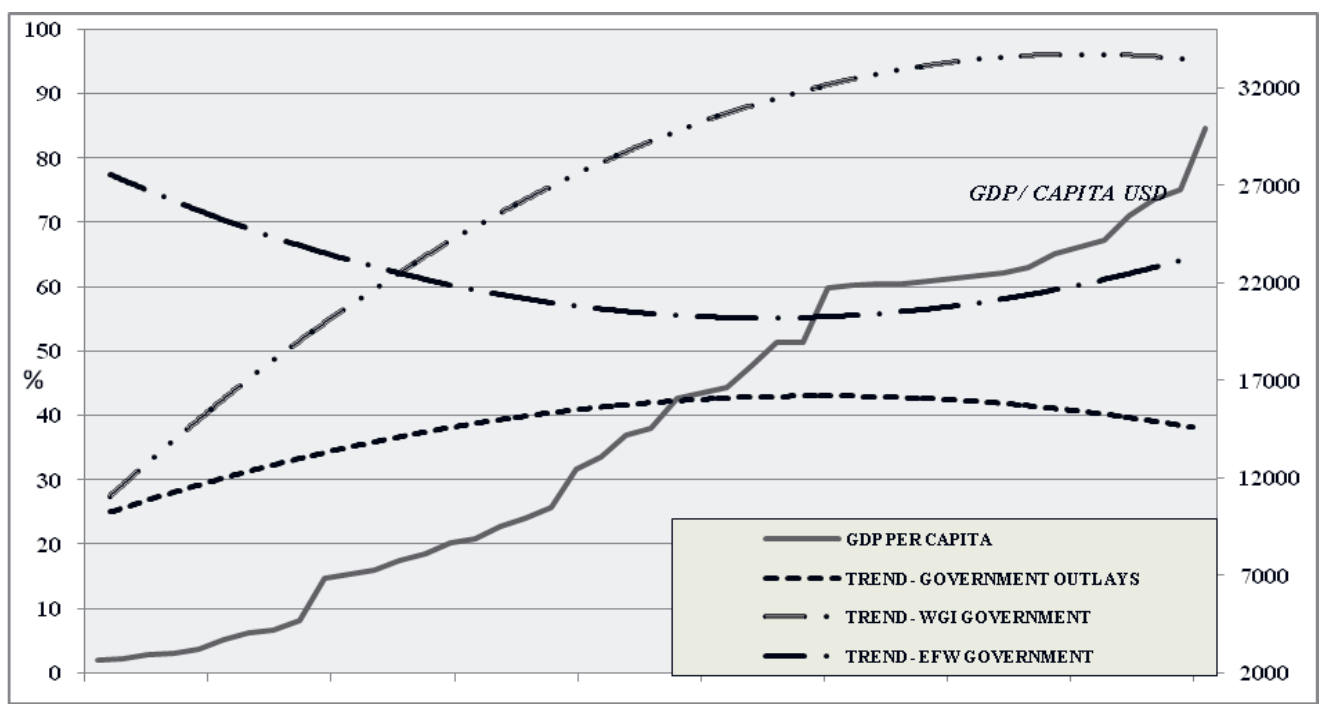

Source: GFS 2007, Maddison 2003, , IFS 2008, Kaufmann-Kraay-Mastruzzi 2009, Gwartney-Lawson 2009 
Figure 12.

\section{General government expenditures, EFW Government indexes - 2005} (45 countries)

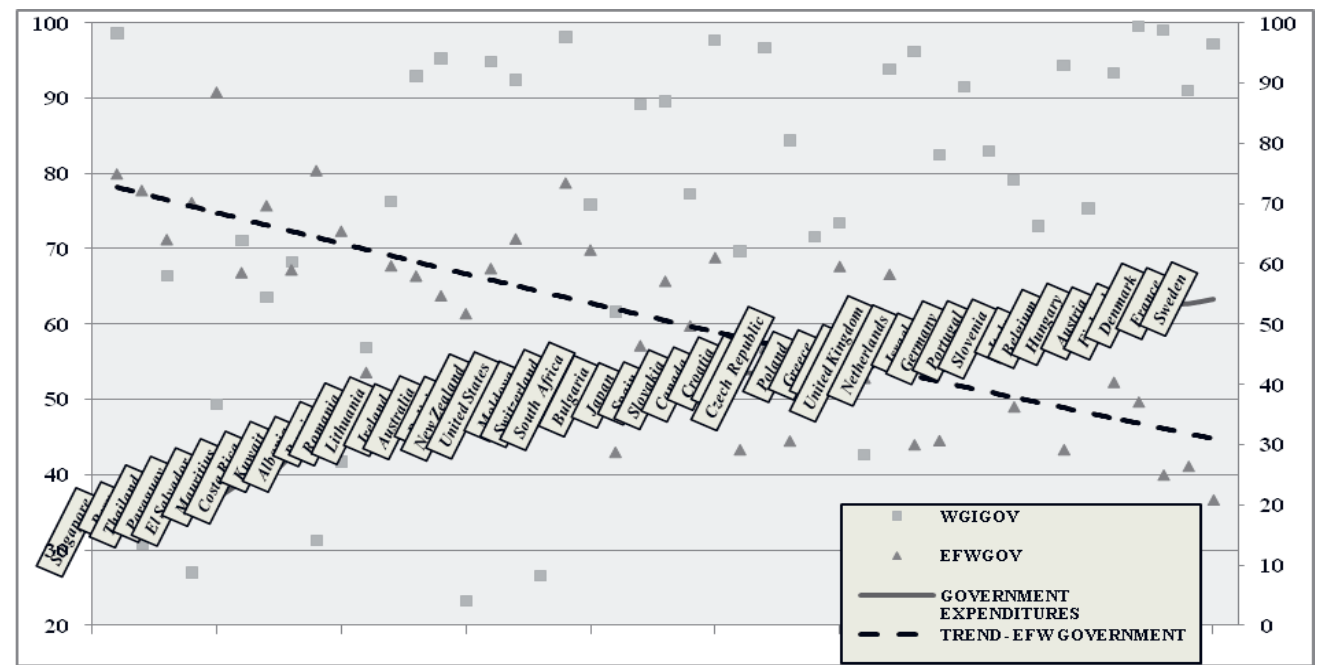

Source: GFS 2007, Maddison 2003, Gwartney-Lawson 2009, IFS 2008,

Kaufmann - Kraay - Mastruzzi, 2009

Both Figure 11 and analysis of the data for the countries show, that on the WGI scale, the most developed countries have attained such a high level in the governmental operation index that in the very highest "class" the value of every single member is similarly outstanding. This is indicated in the figure by the flattening of the WGI governmental index at the level of the highest developmental state.

In Figure 12, the countries are featured in order of the magnitude of national expenditure rather than developmental state in comparison with the GDP. Also in this case it is experienced that there is no close connection between size and the WGI governmental index, the latter are scattered to a large extent, as seen on the Figure. The connection between the extent of the state and the freedom index with regard to the government is all the stronger, and not surprisingly inverted. This is a clear and close correlation; it is no coincidence that, as has been seen earlier, of the former socialist countries it is Albania which has the greatest governmental freedom, which in reality often signifies the weak and powerless effect of the role played by the state.

With a chart reminiscent of a flower, Figure 13 summarises the lessons learnt so far from the comparative analyses carried out in this section. The 45 countries included in the study can be seen in the figure in the order of significance of national expenditure, this is shown by the diagram in the middle. The governmental index of economic freedom is the next on the figure, which is larger for the smaller states, and much smaller for those with extensive national expenditure. The outermost, irregular "flower petal" is the index estimating governmental efficiency.

A combination of the three indices studied shows that the developed capitalist economies differ from one another in many ways, as regards the role played by the state. 
This is also true within Europe, but at the same time this analysis reinforces the differences between developed economies of Europe and those overseas. These are also well perceived from Figures 14 and 15. As can be seen in Figure 14, the three large groups of developed European countries, southern, Scandinavian and the rest of the European economies, the determinative members of which are continental type states but in this regard the United Kingdom may also be listed here, in part display divergent characteristics. A common feature is that the ratio of the national expenditure to the GDP is relatively high, but whilst in the southern states the WGI governmental index as a measure of quality features is relatively low, a value close to the maximum is found in the Scandinavian countries. In the continental economies this value is located between the two.

Figure 13.

General government expenditures, EFW and WGI Government indexes - 2005 (45 countries)

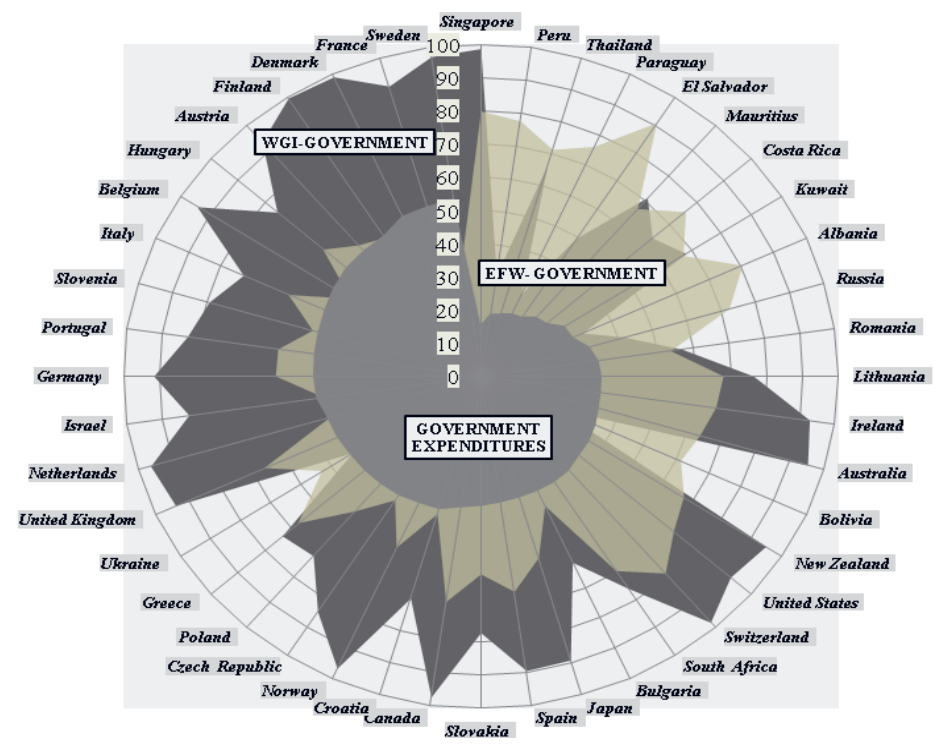

Source: GFS 2007, Gwartney-Lawson 2009, IFS 2008, Kaufmann-Kraay-Mastruzzi 2009 
Figure 14.

Government expenditures, EFW and WGI Government indexes, Europe - 2005

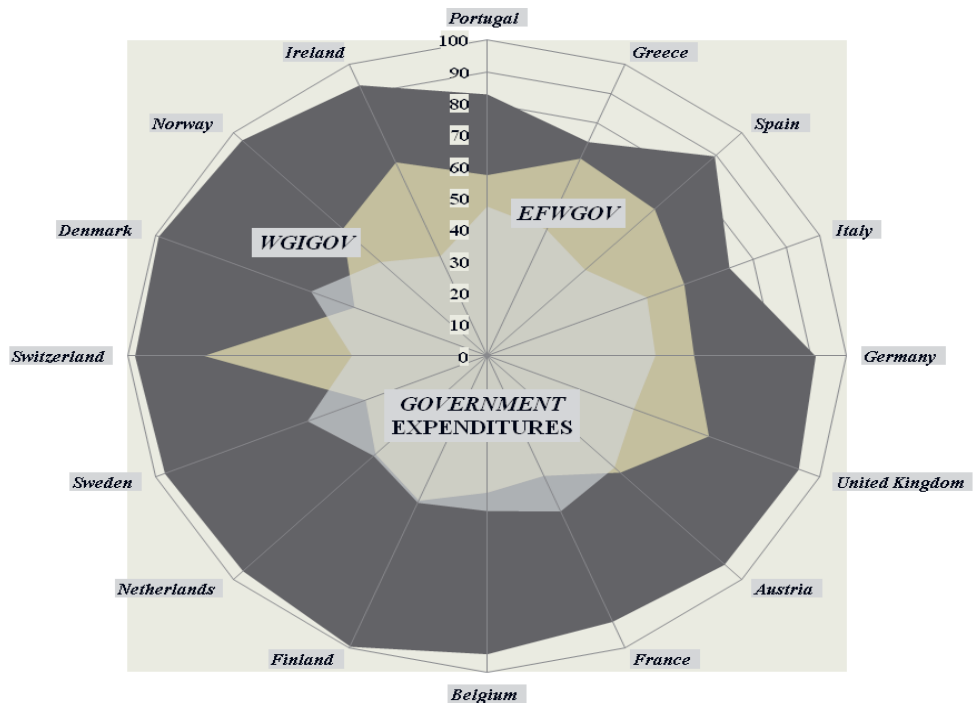

Source: GFS 2007, Gwartney-Lawson 2009, IFS 2008, Kaufmann-Kraay-Mastruzzi 2009

\section{Government expenditures, EFW and WGI Government indexes, Non EU OECD - 2005}

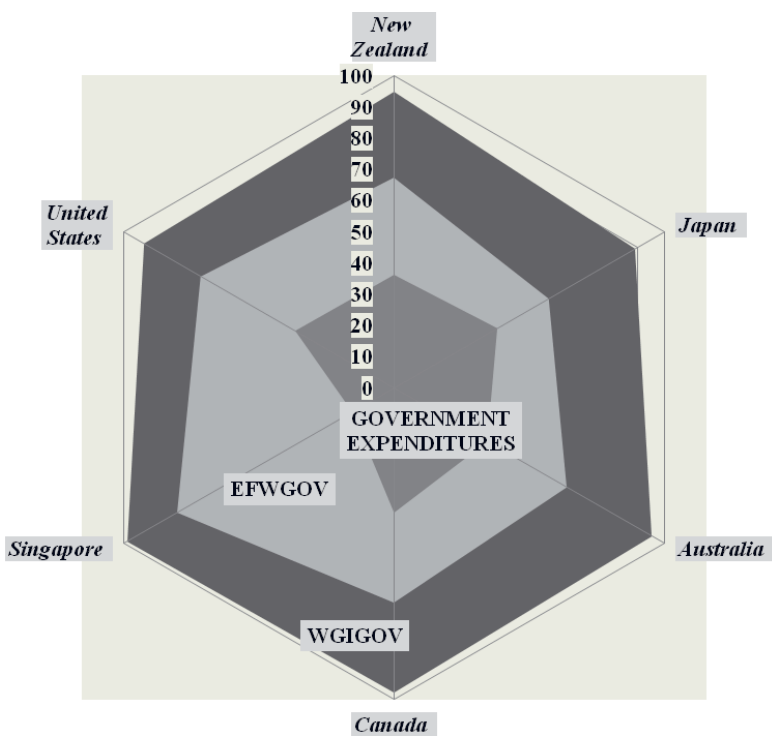

Source: GFS 2007, Maddison 2003, Gwartney-Lawson 2009, IFS 2008, Kaufmann-Kraay-Mastruzzi 2009

Figure 15. 
At the same time, the overseas developed countries show a relatively unified picture. The national expenditure proportion is lower than in the European countries, the governmental freedom index higher, and a picture of a very efficient state is delineated on Figure 15.

\section{The former socialist countries}

We have already seen that in spite of the twenty year transformation process, the overall lag behind the developed countries is rather large. If the national expenditure, the EFW and the WGI governmental indices are also compared in more detail in the other half of Europe, in the former socialist lands, even in the leading countries, characteristics similar to the southern group of the more developed European states are found. A similar conclusion could be reached earlier for the indices showing governmental quality on Figure 5. Values for 13 economies in transformation are presented on Figure 16.

Figure 16.

\section{Government expenditures, EFW and WGI Government indexes - Former socialist countries - 2005}

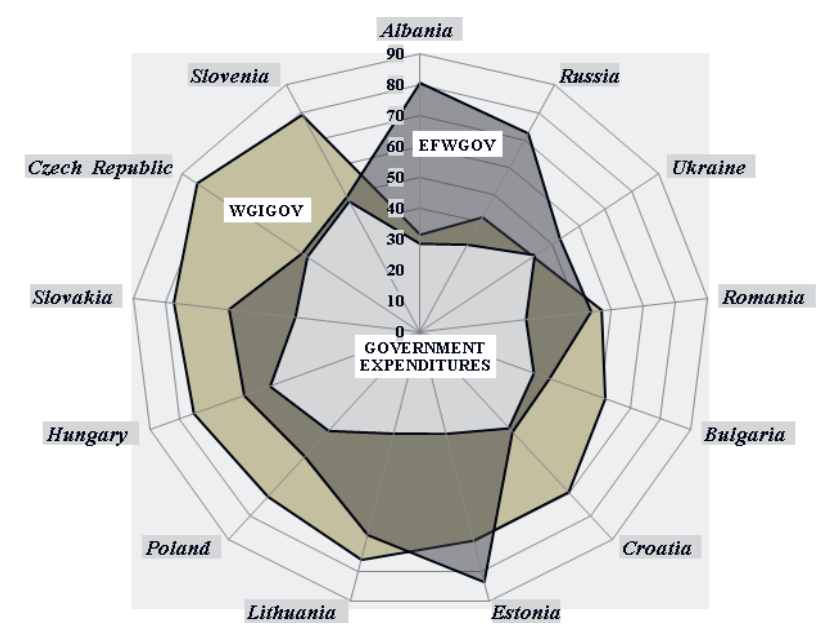

Source: GFS 2007, Maddison 2003, Gwartney-Lawson 2009, IFS 2008

Kaufmann-Kraay-Mastruzzi, 2009

Due to data restrictions, only these economies in transition could be analysed now, but even so, groups with differing characteristics can be outlined. 9 countries, the majority of the 13 examined, are members of the European Union, 4 are not. With regard to their developmental state, Albania is to be found at the end of the line, as well as the two successor states of the former Soviet Union, Russia and Ukraine. In these countries the value of the index measuring the quality of government is very low, besides this the magnitude of national expenditure in Albania and Russia is low, around 30\%, and the state is very "free". A small but powerless state is found here. In Ukraine, on the other hand, the national expenditure encapsulates $43-44 \%$ of the GDP, so it sits more firmly on the economy than in 
the two countries mentioned previously, and allows less freedom. Its efficiency, however, is similarly low. Here a large but powerless state is seen.

The fourth non-EU country is Croatia, though it is supposedly close to joining. According to the phenomena examined here it appears ripe for accession, as it is economically more developed and the operation of the state more efficient than in Romania or Bulgaria.

\section{Government expenditures, EFW and WGI Government indexes - Former socialist countries - 2005}

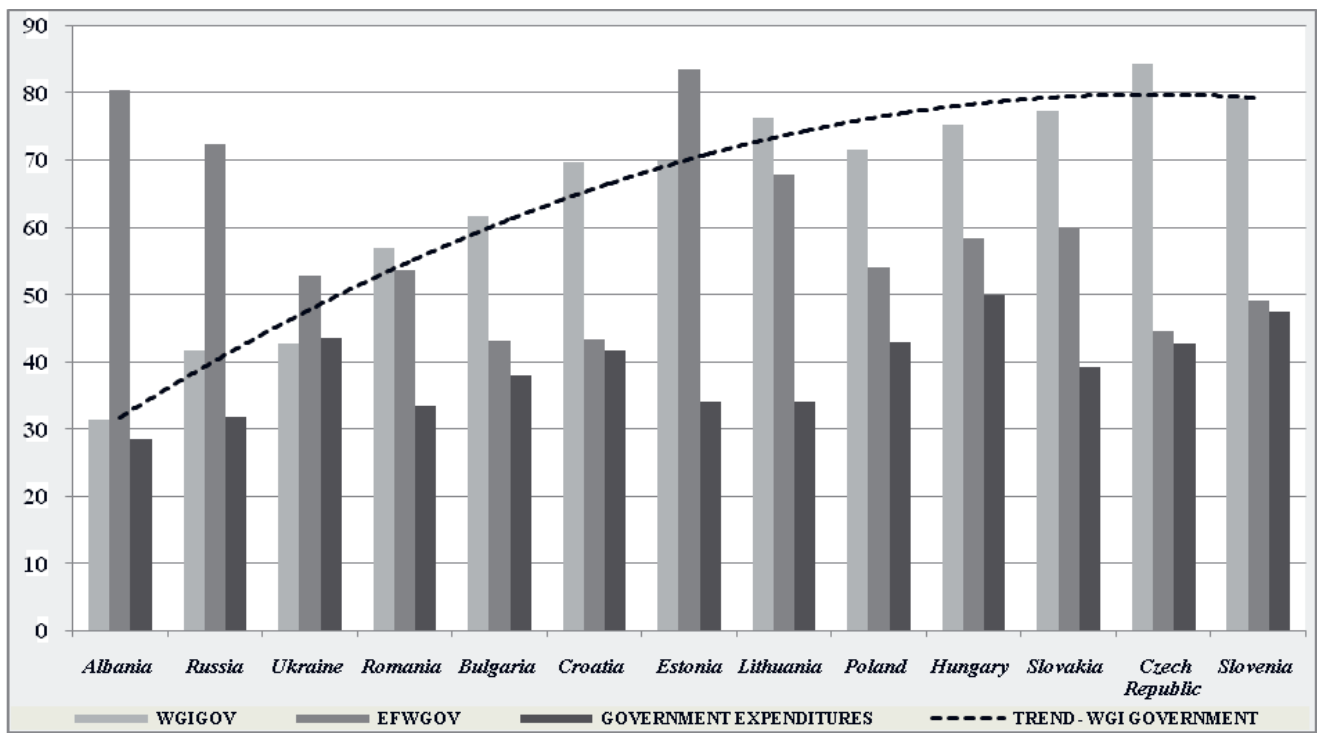

Source: GFS 2007, Maddison 2003, Gwartney-Lawson 2009, IFS 2008, Kaufmann-Kraay-Mastruzzi, 2009

Of the EU member states, the two countries which joined later, Bulgaria and Romania, are at a lower level of development than the states of the first cycle, and their governmental efficiency is also lower. The proportion of national expenditure is somewhat higher in Bulgaria than in Romania, and the governmental freedom index here is the lowest of all the 12 countries examined. All of the Visegrad States are featured in the sample, including Slovenia too. With regard to the national expenditures Slovakia has "left" this group, having managed to reduce the formerly high level to under 40 percent, thus approaching the Baltic States. At the same time, the governmental efficiency index is the second highest here after the Czech Republic and Slovenia, and the governmental freedom index is the largest of all the Visegrad Group. In all these characteristics, it displays similarity with the Baltic States featured here, Lithuania and Estonia. The Czech Republic, Poland, Hungary and Slovenia can be listed in the "remnant" Visegrad Group. In these the governmental efficiency index is high, but so is the magnitude of national expenditure compared to the GDP. The governmental freedom index, however, is relatively low. 
From an examination of the former socialist countries, it can be seen that by the first decade of the millennium the overweight state of the previous period has lost ground everywhere, but the magnitude is diverse even now. The national expenditure centralisation is the highest in the Visegrad States, with values between 42 and 50\%. It has fallen below 40\% in Slovakia, and is around the same in Croatia. In the Baltic States it is around 35\%. In the less developed countries under investigation the magnitude of national expenditure centralisation is very scattered, $43-44 \%$ in Ukraine, and less than $30 \%$ in Albania. The GWI index for governmental efficiency, however, shows a close correlation with the developmental state of the countries studied, as can be seen in Figure 17. It is the highest in the Czech Republic, Slovenia and Slovakia, and the lowest in Ukraine, Russia and Albania.

The governmental freedom index shows a diversified picture. Similarly to the experiences in the broader international study, on the one hand the value is high for the largely undeveloped countries, and also for more developed economies which have a state with less weight but greater efficiency. Russia and Albania can be listed with the former, perhaps the Baltic States with the latter. Estonia has the highest EFW governmental index, greater than $80 \%$, and Lithuania is the third highest with only Albania (!) between them. For the Baltic States, however, as indicated earlier, this could also signify a powerless state in a certain sense. (Csaba 2009)

\section{A different manifestation of the operation of institutions}

In the preceding, an attempt has been made to present the quality of the operation of institutions in the economies in transition. In international comparative studies, the magnitude and extend of corruption is also used as a kind of gauge or "mirror" of the operation of institutions (Keren-Ofer 69). High corruption can also be a kind of index number of the low level of efficiency in operation of the state and the administration of justice.

Besides the earlier comparisons, another test for measuring economic freedom is included in Figure 18. A joint test of the Heritage Foundation and the Wall Street Journal (Holmes-Miller 2010) is the Index of Economic Freedom (WEF). This also includes an index related to corruption, as does the World Governance Indicators test. These two indices are shown on Figure 18 for various country groups. Besides this, the Heritage/Wall Street index constitutes two indices with regard to the government. In a similar way to the other two tests, one of them is the governmental freedom index, which basically corresponds to the dimension of the state. The other is linked with the activity of the state: this is the fiscal policy freedom index. 
Figure 18.

Government expenditures, EFW and WGI Government indexes - 2005

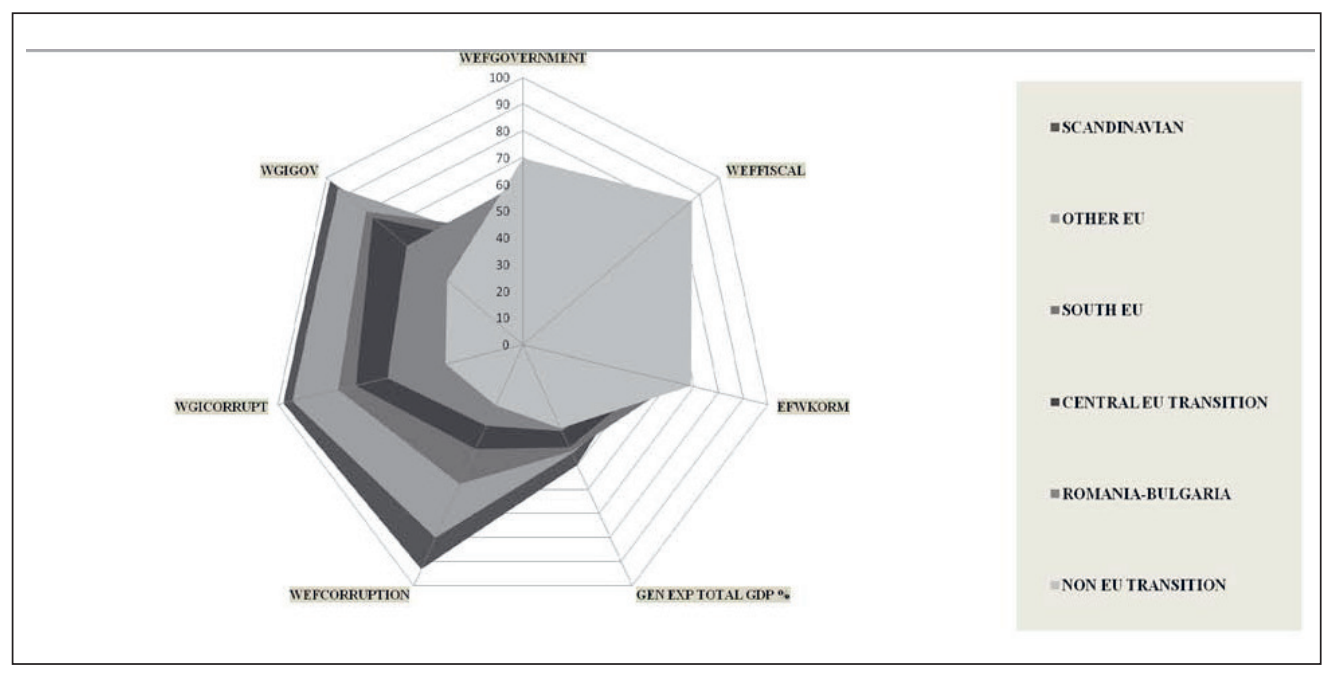

Source: GFS 2007, Gwartney-Lawson 2009, Kaufmann-Kraay-Mastruzzi 2009

In Figure 18, a striking difference is shown up between the various country groups. This corresponds more or less to what was experienced for the WGI governmental index. The corruption indices, particularly calculated according to WEF, display very significant differences. In developed Europe, the Scandinavian countries come out the best and the southern states the worst. But even these latter signify a better level than the leading economies under transformation. The government, on the other hand, provides greater freedom in the undeveloped countries, exercising less influence on the economy here.

A broader picture has been sketched by including the developed capitalist countries, then the former socialist country group has been analysed.

\section{State and market in the former socialist countries}

Europe is the birthplace of modern societies. A long road lasting many centuries led to the development of the capitalist economies by the $19^{\text {th }}-20^{\text {th }}$ centuries. In the interactive process of world economy, a society based on the market and value improvement became determinative. Former "economic worlds" (Braudel 1992) were integrated into a "world economy". The market became the dominant form for the organisation of production. In the countries providing the pattern, organic evolution lasting several centuries has created a model which signifies, or may well signify a goal to be achieved for a great many countries, but at the same time it is questionable whether it is at all possible to copy, overtake, or even outdistance these societies (North-Wallis-Weingast 2008). The complexity of the process, and the significance of the evolutionary development of the institutions is indicated by the work of Friedrich Hayek, and the concept of "Extended Order" which he uses. As he wrote: "our civilization depends, not only for its origin but also for its preservation, on what can 
be precisely described only as the extended order of human cooperation, an order more commonly, if somewhat misleadingly, known as capitalism" (Hayek 1989:6).

During the last century, mainly following the Second World War, the state took on an increasingly greater role in the leading market economies, and by today it is quite justified to call them mixed economies. At the same time, this role played by the state evolved in a market environment, where the two institutions constantly interacted with one another. It is also highly essential, that although quiet, the market was and remains the determinative force in this, and not the "noisy" state. The state was formed over a period of decades by a process of gradual refinement, and the better the accord between the two institutions, the greater the efficiency of operation, whereas if they broke away from one another, this led to increasing operational defects. The direction of development proceeded from the market to the greater state, in an organic way, though not always without conflicts. Although the developed western world was affected by the great world wars, development was still unbroken, two or three centuries having been available for this. Taking a close look at the members of the "elite" club, a great many differences are of course found, but they still belong to one family and are members of one system. Thinking in terms of a systems approach, their coherent common features form a characteristic unit. (Kornai 2000)

The socialist economies formed a different system, the characteristics of which also hung together as arranged in a unit. (Kornai 1992). In order for this system to have become naturalised at all, particularly in Russia, the land of its birth, there were long and deeply embedded historical and social precedents. (Berend 2006) These regions of Central and Eastern Europe were passed over by the mainstream of Europe as sketched out about, or at least they played a subordinate role for many centuries (Szücs 1988). Here the change of regime from feudalism to capitalism came about late and in a distorted way at the end of the $19^{\text {th }}$, beginning of the $20^{\text {th }}$ century. And this occurred decisively not as a result of internal organic evolution, but under the disruptive influence of the expanding modern world system. In the decades of crisis following the First World War, totalitarian systems came into being in the peripheral and semi-peripheral regions: fascism and socialism. (Berend 1998) The communist takeover of power in Russia at the same time meant the replacement of the capitalist system, still being established in a truncated form, by a centralised planned economy carrying out forced industrialisation in the hopes of catching up.

Following the Second World War, once again in consequence of world political circumstances, this expanded into the area of Central-Eastern Europe. There where it was born, in the Soviet Union, the great experiment failed by the end of the century. It collapsed and fell apart there, burying under itself the satellite states too. The same capitalist system, which over many centuries of organic evolution developed the leading economies and societies in the centre with centrifugal dynamics, repelled the states on the edge of the system in a centripetal way, or left areas of vacuum where totalitarian systems could and did break in. These never signified a historical alternative, however, their downfall was of necessity, but they demanded incredible sacrifices from a succession of generations.

The centralised planned economies had collapsed by the nineties, once again resulting from external influences in Central-Eastern Europe. The previously detached elements were "restored to favour" by the capitalist world economy. Over one long century the countries of this region had been affected by three changes of regime, not once according to its own "time table". From feudal, traditional society, in a rather imperfect way, somehow, they switched over to capitalist methods, then the system of socialism "broke in". After this 
had collapsed, they "received" the mixed economy model, which had evolved by then, and which they now had to follow. What a difference - organic evolution over several centuries, or constantly accepting historical influences from outside. In the developed countries, the extended system seen today has been grounded on the evolutionary development of formal and informal institutions over centuries. The fate of the Central-Eastern Europe countries, on the other hand, has been determined much more by historical impacts and external influences with regard to their internal development in the modern age. As expressed by Hayek, historical accidents also play an important role in development, and the role of these may be compared to the significance of mutations in evolution (Hayek 1988:20). But we also know from evolutionary processes, that mutations may of course advance development, even by leaps and bounds, but in other cases they very frequently can and do signify a dead end.

It is worth while examining and evaluating the transformation process and institution building in the former socialist countries over the last two decades with regard to their position in this broader historical stream. Over four decades, these states constructed a distinctive institutional system, in which the state and bureaucratic coordination were determinative, and the market could only affect things in an extremely limited way. Here the formal institutions dictated by socialism were determinative, and these were established rapidly and forcibly with centralised control. The institutions coming from outside settled on the lives of generations who had been socialised in a completely different social system. "Resolution" of the inevitable conflict was partially accomplished by dictatorial suppression, though explosive "failures" occurred at times, such as in 1953 in Berlin, in 1956 in Poznan and then in Hungary. What perhaps signified an even greater problem for operation of the socialist system was that the rapidly established institutions stood in sharp contrast to the deeply rooted customs, traditions and values, which further aggravated the low efficiency typical of the system from the start.The socialist period of Central-Eastern Europe spanned four decades and two generations. At the time of the change of regime the great majority of the active population and the bulk of those carrying out the changes had been socialised in the centralised planned economy system, where there is a sharp contrast between the level of the formal and informal institutions, but the influence is not at all just in one direction. Not only is the operation of the institutions introduced from outside modified by the attitude and approach of the population, but the latter is also constantly shaped by the socialist set-up.

The break-up of the Soviet Union also "liberated" Central-Eastern Europe, where a further change of regime commenced with tempestuous speed. It is true that this now opened the door to the mainstream of world economic development, and in contrast to the situation after the Second World War, the adoption of a successful model was on the agenda. The constant challenge of many centuries was once again on the agenda: to catch up with the most highly developed states of the continent and the world. The "conceitedness" of the centralised planned economy (Hayek 1988) was swept away by the storm of the historical change of regime, but it is as if the states of the region and their expert consultants fell into somewhat similar illusions. Now it is not the socialist system which must be built deliberately, with centralised control, but the market economy, the modern mixed economy.

The situation was contradictory, after all, over the four decades of communism these countries had dropped out of the mainstream of development and lagged behind the majority of the world in many ways. There was no other option than rapid building of the market as 
directed by the state; the "visible hand" fashioned the "invisible hand" indispensable for the new system. This accelerated development, in contrast to the historical route, led from the state to the market here rather than the other way round. On the one hand the state had to build the market institutions, on the other, it had to deconstruct its previous dominance, its almost exclusive economic authority. To demolish and transform itself, and construct its own antithesis, is no everyday challenge.

Besides this, something had to be established in the region which had never existed here; this system evolved in its modern form elsewhere, and it had to be replanted here. A "living" organism had to be created by inorganic, radical intervention, which would later be capable of organic advancement. The heightened role of the state in the change of regime was not completely new in the region, after all, it was also perceptible in the transformation from feudalism to capitalism and industrialisation, particularly in the eastern centre of the region and on its edge (Gerschenkron, 1962, Berend-Ránki 1974). In the second, socialist transformation, of course, state control was self evident and exclusive. The clarity of the situation helped to determine the pattern to be followed, and in truth, taking more or less similar steps, within a short time the countries of the region had established the framework of the new system and the most important institutions, and the importance and role of the state had been driven back or transformed. This can also be easily perceived from an empirical analysis of the first section of this study.

Beside the institutions at the macro-level, micro-level transformation was also an important step: establishment of the modern corporate sphere. The institution building by the state provided a framework for this, but it could not have implemented it by itself. The truly significant breakthrough here was represented by the adoption and inrush of foreign patterns, in which a key role was played at the regional level by a significant influx of capital. This is really no novelty in the region, as at the end of the $19^{\text {th }}$ century, beginning of the $20^{\text {th }}$, foreign capital also played a prominent role in the first capitalist transformation. At the present time the most successful players in the competitive sector are in foreign hands, as is the bulk of the banking sector. At the same time a significant proportion of enterprises with domestic capital today are unable to compete on the international markets; a kind of dual corporate structure has come into being.

Institution building occurred relatively rapidly and successfully in the region of CentralEastern Europe, and the more developed was the country in transition, the more successful was the adoption of the institutional patterns fashioned in the developed countries, as least at far as the forms are concerned. This has been seen earlier in the international comparative study for the case of the Visegrad and Baltic States. At the same time it has also been seen, and reinforced by much additional experience, that the efficiency of operation of these institutions lags considerably behind those observed in the model states. In fact, according to our investigations, during the period from the rapid transformation in the nineties until today, after domestication of the new system, this efficiency has not improved further. It has more or less stabilised at a relatively low level, in fact, a fall is observed in certain places.

Three changes of regime within a century, induced from outside, provide a common lesson in one way. Transformation and reform of formal institutions is much easier than retailoring the informal institutions, customs, conventions and traditions interlacing the society and the economy, and adjusting to the new forms. In fact, it is very often these deeply influential traditions and means of behaviour which modify the newly established institutions. As Hayek wrote in the foreword to the American edition of the Road to 
Serfdom: "the political ideals of a people and its attitude toward authority are as much the effect as the cause of the political institutions under which it lives." (Hayek 2007:48)

Socialism was born in Russia, in the midst of a historical dilemma in many ways. After the Second World War this model, the "uniform" of classical socialism was pulled over countries with very different traditions and stages of development, from Mongolia to Poland, from Albania to Hungary. The "clothes" may have been the same, but they were worn and tolerated differently by the various societies, and this rebounded on the quality and formation of socialism in the individual countries. The more developed an affected country was, the more the effects of the earlier bourgeois mentality came to the fore, and the stronger was the contrast between the levels of the formal and the informal institutions. This is why the explosions of various kinds occurred in the most developed members in the fifties. The socialist model is much more suitable, at least for a time, for the quantitative development of countries at a low developmental stage, than for the operation of moderately developed economies. Expressed another way, there is a much greater loss of efficiency resulting from the non-market system in this latter case. An increase in the relative shortfall compared with the market economies occurred specifically as a result of these losses.

Alongside much that was identical, therefore, the socialist countries also differed in many ways. One of the main reasons for this is rooted in the fact that when the change of regime occurred after the Second World War, the conventions, cultures and traditions of the Central-Eastern European countries were very divergent. Citizens who had been socialised under the earlier system had "built", fashioned, formed and of course endured the new system for decades. By the time the generations born into socialism were entering adult life in the seventies and eighties, the system was already approaching its end. More apparent aspects of the differences between the countries were, for instance, the appearance of market socialism in Hungary and Poland, and the short-lived experiment of Prague Spring in 1968.

Problems with the system appeared more sharply and more perceptibly in the western area of the eastern bloc, in the more developed countries, and in order to handle these, they had to "sacrifice" more resources than the less developed members. The way to do this, essentially due to the nature of the system, was primarily to raise the level of communal consumption, and to a lesser extent increase personal consumption. Certain possibilities for change-over presented themselves to the leaders of the system, from the application of the violent instruments of dictatorship to the increase of consumption. The Soviet Union, or for instance Romania, leaned generally towards the first pole, but this was much more difficult to apply in the more civilised countries. Partly due to the more democratic traditions, and partly because of the nearness of the west, the example of the standard of living there being perceptible in spite of closed borders.

As Yevgeni Preobrazhensky had already sketched out in the 1920s, alarmingly but with haunting foresight, the centralised planned economies (Preobrazhensky 1926), regrouped all resources into forced industrialisation, and in this a decisive role was played by keeping wages low and the accumulation rate extremely high. At the beginning, this could be represented as a temporary sacrifice made for future abundance, "don't eat the goose that lays the golden egg", but not for ever. There was no way abundance was coming. The real situation was masked by that bogus illusion, that wages are low because the state will take care of all needs, free of charge, such as education, medication, pensions, recreation, etc.. The ideology of paternalism, mainly at the beginning, served the purpose of things being taken away from the population on the whole, rather than given to them. 
In the less developed states applying a more severe dictatorship, this remained characteristic throughout the whole period of the system. At the time of the change of regime in the nineties, the socialist state was presented as the cause of oppression and deprivation. In the more developed region, naturally to varying degrees here too, the state redistributed more back to the population in the form of social benefits, and at the time of the changes this was fixed in their consciousness as a state role to be retained. Beyond this is fact, many long term promises were made on maintaining the socialist state in the future. In general, however, even in these countries the importance of consumption as a whole was low, in particular personal consumption. From the other side, of course, the efficiency of the economies was of a very poor standard, as became clear at lightning speed from the market trial performed by means of liberalisation in the nineties. As a result, the redistribution affecting the population at varying levels, and the fixing of this in the expectations of the people, created differing situations in terms of what was expected from the state in the individual economies in transition. Though important in terms of our subject, a stronger or weaker paternal attitude is of course just one consequence of the differing developmental routes taken by the counties.

Looking in the longer term at the development in the region, fragmented as it is by external shocks, a kind of interactive, dual spiral can be considered. Generations living in a given system are borne by a current which is partially determined by the framework of characteristic institutions, but also strongly influenced by traditions and conventions carried forward and inherited from earlier times. The formal institutions influence people's concepts and actions, but at the same time, the people also fashion their own institutions and their operation. If this occurs as long-term, organic evolution, then there is time for the two spheres to develop harmoniously. Over the period of the last hundred years in Central-Eastern Europe, this was not the case. At the end of the $19^{\text {th }}$ century, the forms of behaviour, traditions and expectations established over the previous centuries found themselves relatively rapidly in a strange formal institutional system which had come from outside. A hard struggle by a succession of generations was needed in order to adapt, but in the meantime capitalism became something essentially different from in the leading model countries. Modernisation of the region was burdened with feudal elements even in the $20^{\text {th }}$ century. A peculiar fragmentation of the dual spiral was also caused by the collapse of empires in the First World War, which involved the formation of new national boundaries. This had a significant effect not only on the formal institutions, but also on the informal. New national states came into being, old empires and national communities disintegrated.

In this situation, following a further world conflagration, the second change of regime occurred, totally inflicted from outside: the rapid and violent introduction of socialism. Conventions and behaviours in sharp contradistinction to the semi-feudal, semibourgeois traditions once again adapted over generations of suffering to the new system, but meanwhile they also modified it, in somewhat differing ways according to region and country. Of course, this also rebounded on these same generations, but more especially on the younger age-groups. By the time the generations growing up under the latest system could take on an active, formative role, a further change of regime had swept through the region.

Copying and domesticating the mixed economy model established by lengthy organic evolution in the developed countries became the common, but also individual task for the countries of the region. For the most part, implementation fell upon the generations 
socialised under the socialist system. The new system was born 20 years ago, but its children have not yet appeared on the scene, nor could they. In the coming decades they will, but these are still before us. Interestingly enough, in parallel with the new change of regime, the map of the region was once again significantly redrawn. The establishment of new states overshadowed the picture, which naturally signifies formal institutional changes, but it has at least as much effect at the deeper level of informal institutions.

A result of the dual spiral outlined above, is that by the first decade of the millennium the characteristics of the former socialist countries are increasingly diverging from one another. It also follows from this that the model is not working at all as described in the textbooks of the western model countries, or as many had expected when the change of regime occurred. Both the characteristics of the earlier socialism, and the more distant historical past which can be caught in the act within it, had and have an effect on the economic and social systems now established in Eastern and Central Europe. The chief vehicle is the informal institutional system, forming very slowly and under the influence of many factors, the current of customs, traditions, values, unwritten rules, beliefs and myths passed down from generation to generation, and the dynamic interaction of these with the formal institutions. A very significant part of all this is what type and character of state and what kind of market was formed in the mixed economies established from above and by external influences after the nineties, and how the relationship between these was established. And it is particularly important how the institutions are linked with the concepts, expectations, customs and traditions of the generations who live in them, considering that three changes of regime have occurred in the region within the lifetime of a total of 6-8 generations, and a number of state boundaries were changed twice in the $20^{\text {th }}$ century.

\section{References}

Berend, T. Iván (1998): Decades of Crisis: Central and Eastern Europe Before World War II. University of California Press, Berkeley-Los Angeles.

Berend, T. Iván (2006): An Economic History of Twentieth-Century Europe. Cambridge University Press. Cambridge - New York.

Berend, T. Iván - Ránki, György (1974): Economic Development in East Central Europe in the 19.th \& 20th Centuries. Columbia University Press. New York.

Bohle, D. - Greskovits, Bela (2007): Neoliberalism, Embedded Neoliberalism and Neocorporatism: Towards Transnational Capitalism in Central-Eastern Europe. West European Politics, 30. 443-446. o.

Braudel, F. (1992): The Perspective of the World. Berkeley-Los Angeles, University of California Press. Berkeley-Los Angeles.

Bruszt, László - Stark, D. (1998): Postsocialist Pathways: Transforming Politics and Propoerty in East Central Europe. Cambridge University Press. Cambridge.

Buchanan, J. M. - Wagner, R. E. (1977): Democracy in Deficit: The Political Legacy of Lord Keynes. Academic Press. New York - London.

Csaba, László (2009): A növekedés, az euró és az egyensúlyhiány. In.: Muraközy László, ed. (2009): A jelen a jövő múltja. Járatlan utak - járt úttalanságok. Akadémiai Kiadó. Budapest. 333-358.

Estrin, S. - Kolodko, W. G. - Uvalic, M. (2007): The Transition and Beyond. Essays in Honor of Mario Nuti. Palgrave Macmillan. Houndmills, Hampshire - New York.

Gerschenkron, A. (1962): Economic Backwardness in Historical Perspective. Belknap Press of Harvard University Press. Cambridge, MA.

GFS (2007): Government Finance Statistics Yearbook. International Monetary Found Washington D.C.

Győrffy, Dóra (2007): Democracy and Deficit. Akadémiai Kiadó. Budapest. 
Gwartney, J. - Lawson, R. (2009): 2009 Economic Freedom Dataset published in Economic Freedom of the World: 2009 Annual Report. Fraser Institute. Vancouver, B.C.

Hayek, F. (1965): The Road to Serfdom. University of Chicago Press. Chicago.

Hayek, F. (1988): The Fatal Conceit: The Errors of Socialism. University of Chicago Press. Chicago.

Hayek, F. (2007): The Road to Serfdom. Text and Documents. The Definitive Edition. Edited by Cardwell, B. University of Chicago Press - Routledge. London.

Holmes, R. K. - Miller, T. (2010): 2010 Index of Economic Freedom. The Heritage Foundation and Dow Jones \& Company, Inc. Washington D.C. - New York.

IFS (2008) International Financial Statistics. International Monetary Found Washington D.C.

Kaufmann, D. - Kraay, A. - Mastruzzi, M. (2009): Governance Matters VIII. Aggregate and Individual Governance Indicators 1996 - 2008. World Bank. Washington D.C.

Keren, M. - Ofer, G. (2007): Are Transition Economies Normal Developing Countries? The Burden of the Socialist Past. In.: Estrin, S. - Kolodko, W. G. - Uvalic, M. (2007) The Transition and Beyond. Essays in Honor of Mario Nuti. Palgrave Macmillan. Houndmills, Hampshire - New York. 58-88. oldal.

Kornai, János (1992): The Socialist System. The Political Economy of Communism. Princeton University Press. Princeton.

Kornai, János (1994): Négy jellegzetesség. A magyar fejlödés politikai gazdaságtani megközelítésben I. rész. Közgazdasági Szemle No. 12. pp. 1097-1117.

Kornai, János (1995): Négy jellegzetesség. A magyar fejlödés politikai gazdaságtani megközelitésben II. rész. Közgazdasági Szemle No. 1. pp. 1-29.

Kornai, János (2000): The System Paradigm. In.: Schekle, W. - Krauth, W. - Kohli, M. - Elwert, G., eds. (2000): Paradigm of Social Change: Modernization, Development, Transformation, Evolution. Campus Verlag. Frankfurt-New York. pp. 111-133.

Kornai, János (2008): From Socialism to Capitalism. Central European University. Budapest - New York.

Maddison, Angus (2003): The World Economy. Historical Statistics. OECD Development Centre Studies. Paris, OECD.

Meltzer, H. A. - Richard, F. S. (1981): A Rational Theory of the Size of Government. The Journal of Political Economy, 89. pp. 914-927.

Muraközy, László (2004): Yet Another Change of System. What Can Be Learnt from History and What Cannot. University of Debrecen. Debrecen.

Muraközy, László (2008): Magyarország felemelkedése és hanyatlása. Közgazdasági Szemle, No. 2. pp. 149168.

North, D. C. (2005): Understanding the Process of Economic Change. Princeton University Press. Princeton.

North, D. C.-Wallis, J. J.-Weingast, B. R. (2008):Violence and Social Orders: A Conceptual Framework for Understanding Recorded Human History. Cambridge University Press. Cambridge.

OECD (2009): Economic Outlook. Volume 2009/2. November. OECD. Paris.

Olson, M. (1982): The Rise and Decline of Nations. Harvard University Press. Cambridge, MA - London.

Polányi, K. (1946): The Great Transformation. The Political and Economic Origins of Our Times, Victor Gollancz Ltd. London.

Preobrazhensky, Yevgeni (1926): Novaja Ekonomika. Kommuniszticseszkaja Akademia. Moszkva.

Schekle, W. - Krauth, W. - Kohli, M. - Elwert, G. eds. (2000): Paradigm of Social Change: Modernization, Development, Transformation, Evolution. Campus Verlag. Frankfurt-New York.

Szücs, Jenö (1988): Three Historical Regions of Europe. In Keane J. (ed). Civil Society and the State. Verso. London. pp. 291-332 